PSICOLOGÍA

IBEROAMERICANA
Psicología Iberoamericana ISSN: 1405-0943

revista.psicologia@ibero.mx

Universidad Iberoamericana, Ciudad de México México

\title{
Investigación y Psicología
}

Turnbull, Bernardo

Investigación y Psicología

Psicología Iberoamericana, vol. 26, núm. 2, 2018

Universidad Iberoamericana, Ciudad de México, México

Disponible en: http://www.redalyc.org/articulo.oa? $\mathrm{id}=133959841001$ 


\section{Investigación y Psicología}

La construcción del conocimiento es lo que identifica al quehacer científico. Pero en el campo profesional el conocimiento se aplica, se utiliza y, también, se compra y se vende. La gran mayoría de los profesionales que utilizan conocimiento científico se limitan a eso, a utilizarlo. Aunque es imposible aplicar conocimiento sin aprender de la experiencia diaria, estos aprendizajes no se registran ni mucho menos se difunden. No todos los profesionales se identifican como constructores activos del acervo de conocimiento que consideran propio.

El campo de la psicología no es la excepción. El número de profesionales de la psicología en nuestro país es ya muy grande; hace años que dejó de ser una profesión minoritaria. Aún así, la proporción de psicólogos que construyen la psicología es mínima. De la misma manera, en el proceso de entrenamiento de nuevos profesionales, enfatizamos la acumulación y el uso de conocimiento sobre su construcción y difusión. Para el gran número de títulos profesionales que se emiten cada año, la proporción de quienes se preparan para la construcción de conocimiento es mínima.

Aunque evidentemente es necesario incrementar el número de investigadores en nuestro país, también sabemos que el proceso de entrenamiento y preparación debe ser selectivo y cuidadoso. El conocimiento psicológico no se construye porque sí. No cualquier conocimiento justifica el costo económico y social que nuestro país invierte en su creación. En el centro de nuestra profesión está el servicio. Se puede servir al cliente individual, al grupo, a la organización humana y a la institución. Existen muchas formas de servicio, pero las profesiones de ayuda tienen que servir a la comunidad que la rodea. Al servir, solucionamos problemas, al solucionar problemas aprendemos, y lo que aprendemos lo compartimos con nuestros colegas para que lo utilicen para servir. Por lo tanto, el entrenamiento del investigador en psicología se centra en crear conocimiento para el servicio.

El proceso es lógico, pero también está inmerso en la sociedad y la vida cotidiana y, como éstas, se va haciendo cada vez más complejo. En estas circunstancias, la investigación está sujeta a una red intrincada de fuerzas sociales, culturales, económicas y políticas. Estas fuerzas la desvían de su propósito original y la van orientando hacia funciones e indicadores cada vez más lejanos de su identidad profesional y científica.

Nuestro sistema de investigación registra minuciosamente las veces que nuestro trabajo se publica y también en qué clase de revistas publicamos. La publicación y la citación tienen un valor académico que cada vez se hace más elitista y colonialista. Hasta el momento, yo no conozco un sistema que mida cómo la investigación contribuye al desarrollo de la comunidad o su aplicación práctica a los problemas de la vida real. Tampoco se considera qué tan útil es nuestra investigación para la gente que nos dio la información que usamos para conseguir una publicación.

¿Cuál es el papel de una revista científica en este proceso de creación y difusión del conocimiento y de su contribución a la solución de problemas? Una revista es la voz de los profesionales que quieren comunicarse con otros y compartirles sus aprendizajes. Aquel profesional que registra sistemáticamente su experiencia mejora su práctica y la calidad de su servicio. Aquel investigador que reporta lo que aprendió en su práctica y lo comparte con sus colegas crea un conocimiento más profundo y lleno de sentido. Ya sea la implementación directa de la investigación aplicada

o la utilidad indirecta pero indispensable de la investigación básica, es el acervo de conocimientos lo que contribuye a que, como comunidad profesional, demos una respuesta sólida a los problemas que nos rodean. 
En este número de Psicología Iberoamericana encontramos una variedad incluyente de temas, aproximaciones, teorías y métodos que nuestros autores ponen a la disposición de todos nosotros para su aplicación en el servicio profesional.

La misión de nuestra revista es ayudar a los psicólogos a comunicarse entre sí, para mejorar la calidad de nuestro servicio y a construir un ambiente de respeto y cooperación.

\section{RESEARCH AND PSYCHOLOGY}

The construction of knowledge is the trademark of scientific activity. However, in the professional field, knowledge is also applied, used, bought and sold. The majority of professionals who use scientific knowledge constrain their activity to that: the use of knowledge. Although it is impossible to apply knowledge without learning from the experience, learning is seldom registered, let alone spread. Not all professionals see themselves as active constructors of knowledge and therefore do not consider it their own.

The field of Psychology is not an exception. The number of professional psychologists in our country is large. It has been years since psychology was considered a profession of the minority. Furthermore, psychologists that contribute to the betterment of psychology is minimal. During the process of training new professionals, we emphasize the accumulation and use of knowledge over its construction and dissemination. From a large number of degrees issued every year, the proportion of those who train with the purpose of contributing to the body of knowledge in the field of psychology is minimal.

Although it is evident that we need to increase the number of researchers in our country, we also know that the training and preparation process must be selective and careful. Psychological knowledge is not made for its own sake. Not just any knowledge is worth the economic and social costs that the country invests in its creation. At the centre of our profession is service. We can serve the individual client, the group, the human organization and the institution. There are many different forms, but we must serve the people around us. When we serve, we solve problems, when we solve problems we learn and, what we learn, we share with our colleagues so they can use it to serve. A researcher's training in psychology should be centred on service.

The process is logical, but it is also immersed in society and daily life and, like these two, it is becoming even more complex. In these circumstances, research is subject to an intricate network of social, cultural and economic forces. These forces deviate research from its original purpose and gradually make it perform functions and fulfill indicators different from its professional and scientific identity.

Research systems accurately register how many publications and citations we have, as well as what kind of journals wepublish in. Publications and citations have an academic value that is becoming more and more elitist and colonialist in nature. At the moment, I am not aware of a system that measures how research contributes to community development or its practical application to real-life problems. How useful our research is for those people who gave us the information we used to get published is also not considered.

What is the role of a research journal in this process of creating and spreading knowledge, as well as helping solve real-world problems? A journal is the voice of professionals who want to share their learning. Professionals who systematically register their experience, improve their practice and quality of service. The researcher, who reports what they learned in their practice and shares it with their colleagues helps create deeper and more meaningful knowledge. Either in the direct implementation of applied research or in the indirect but indispensable use of basic research, it is the body of knowledge that contributes to solving the problems around us.

In this issue of Psicologia Iberoamericana, we find an inclusive variety of themes, approaches, theories and methods that our authors place at our disposal for its application in professional service.

The mission of our journal is to help psychologists communicate with each other to improve the quality of our service and encourage a professional environment of respect and cooperation. 